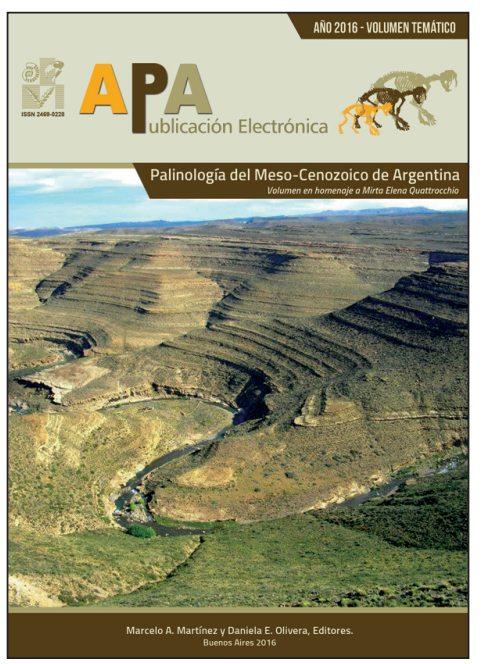

\title{
REVIEW OF THE PALAEOENVIRONMENTAL RECONSTRUCTION OF LATE QUATERNARY MARINE SEQUENCES, TIERRA DEL FUEGO (ARGENTINA)
}

MARÍA S. CANDEL1

ANA M. BORROMEI

\begin{abstract}
${ }^{1}$ Centro Austral de Investigaciones Científicas (CADIC-CONICET), Bernardo Houssay 200, 9410 Ushuaia, Tierra del Fuego, Argentina.
${ }^{2}$ Instituto Geológico del Sur (INGEOSUR-CONICET), Departamento de Geología, Universidad Nacional del Sur. San Juan 670, B8000ICN Bahía Blanca, Buenos Aires, Argentina.
\end{abstract}

Recibido: 28 de marzo de 2016 - Aceptado: 16 de agosto de 2016

Para citar este artículo: María S. Candel and Ana M. Borromei (2016). Review of the palaeoenvironmental reconstruction of Late Quaternary marine sequences, Tierra Del Fuego (Argentina). En: M. Martínez y D. Olivera (Eds.), Palinología del Meso-Cenozoico de Argentina - Volumen en homenaje a Mirta Elena Quattrocchio. Publicación Electrónica de la Asociación Paleontológica Argentina 16 (2): 184-201.

Link a este artículo: http://dx.doi.org/10.5710/PEAPA.16.08.2016.112

DESPLAZARSE HACIA ABAJO PARA ACCEDER AL ARTÍCULO

Asociación Paleontológica Argentina Maipú $6451^{\circ}$ piso, C1006ACG, Buenos Aires República Argentina Tel/Fax (54-11) 4326-7563 Web: www.apaleontologica.org.ar

Otros artículos en Publicación Electrónica de la APA 16(2):

Martínez \& Olivera

JURASSIC ORGANIC-WALLED

MARINE MICROPLANKTON FROM

THE NEUQUÉN BASIN. DISTRIBUTION, BIOSTRATIGRAPHY AND PALEOBIO-

GEOGRAPHY. A REVIEW

\section{Guler, Paolillo \& Martz}

EARLY CRETACEOUS DINOFLAGELLATE CYSTS FROM THE NEUQUÉN AND AUSTRAL BASINS: A REVIEW
Deschamps \& Tomassini

LATE CENOZOIC VERTEBRATES FROM THE SOUTHERN PAMPEAN REGION: SYSTEMATIC AND BIO-CHRONOSTRATIGRAPHIC UPDATE 


\title{
REVIEW OF THE PALAEOENVIRONMENTAL RECONSTRUCTION OF LATE QUATERNARY MARINE SEQUENCES, TIERRA DEL FUEGO (ARGENTINA)
}

\author{
MARÍA SOLEDAD CANDEL ${ }^{1}$, ANA MARÍA BORROMEI ${ }^{2}$
}

${ }^{1}$ Centro Austral de Investigaciones Científicas (CADIC-CONICET), Bernardo Houssay 200, 9410 Ushuaia, Tierra del Fuego, Argentina. soledadcandel@cadic-conicet.gob.ar ${ }^{2}$ Instituto Geológico del Sur (INGEOSUR-CONICET), Departamento de Geología, Universidad Nacional del Sur. San Juan 670, B8000ICN Bahía Blanca, Buenos Aires, Argentina.borromei@criba.edu.ar

\begin{abstract}
This work is an updated review of the knowledge on the evolution and development of palaeoenvironments during the Holocene marine ingression and posterior regressive event in Tierra del Fuego. During the beginning of the marine transgression, ca. 8,000 cal yr BP, the vegetation in the southern coastal areas along the Beagle Channel was mainly arboreal with dominance of Nothofagus forest and scarcity of shrub and herbaceous communities, while in the northeastern Atlantic coast, the treeless steppe was replaced by a relatively open Nothofagus forest. The Early-Middle Holocene aquatic assemblages were characterized by a scarce occurrence of marine components, especially dinoflagellate cysts, suggesting the development of low energy estuarine environments with low-salinities caused by glacier meltwater discharge. After $6,000 \mathrm{cal}$ yr BP, an increase in the number of aquatic species was observed with dominance of Peridiniales dinoflagellate cysts, indicating the establishment of marginal marine environments with low to moderate salinities and high nutrient levels. During the last 1,000 cal yr BP, the littoral vegetation along the Beagle Channel showed an open Nothofagus forest and the development of peatlands, while in the northeastern Atlantic coast the steppe vegetation developed under less humid environmental conditions related to the marine regressive event. These assemblages have a similar composition to those observed in modern sediments of the Beagle Channel and suggest palaeoenvironmental conditions comparable to today.
\end{abstract}

Key words. Palaeoenvironments. Marine sequences. Late Quaternary. Tierra del Fuego.

Resumen. REVISIÓN DE LA RECONSTRUCCIÓN PALEOAMBIENTAL DE SECUENCIAS MARINAS DEL CUATERNARIO TARDÍO, TIERRA DEL FUEGO (ARGENTINA). Este trabajo es una revisión actualizada del conocimiento sobre la evolución y desarrollo de los paleoambientes durante la ingresión marina del Holoceno y su posterior regresión en Tierra del Fuego. Durante la incursión marina ca. 8.000 años cal AP, la vegetación en las zonas costeras a lo largo del Canal Beagle estuvo dominada por el bosque de Nothofagus con escasos arbustos y hierbas, mientras que en la costa atlántica la estepa fue sustituida por un bosque de Nothofagus relativamente abierto. Las asociaciones acuáticas desarrolladas durante el Holoceno Temprano-Medio se caracterizaron por una escasa ocurrencia de componentes marinos, especialmente quistes de dinoflagelados, sugiriendo el desarrollo de ambientes estuarinos de baja energía y salinidad, afectados por la descarga de agua de los glaciares. Después de los 6.000 años cal AP, se observó un aumento en el número de especies acuáticas con dominancia de quistes de dinoflagelados Peridiniales, lo que sugiere el desarrollo de ambientes marinos marginales con baja a moderada salinidad y alto contenido de nutrientes. Durante los últimos 1.000 años cal AP, la vegetación litoral a lo largo del Canal Beagle mostró el predominio de un bosque abierto de Nothofagus y turberas, mientras que en el noreste de la costa atlántica se desarrolló una vegetación de estepa bajo condiciones ambientales menos húmedas y relacionadas al evento marino regresivo. Estas asociaciones tienen una composición similar a las observadas en los sedimentos modernos del Canal Beagle y sugiere que las condiciones paleoambientales fueron comparables a las actuales.

Palabras clave. Paleoambientes. Secuencias marinas. Cuaternario Tardío. Tierra del Fuego.

THE LATE Quaternary palynological studies, particularly of the Late Pleistocene-Holocene, represent a research line of growing interest in Argentina since they provide important information about the variability of past environments. About 15,000 years ago, the climate of the southernmost region of South America underwent irreversible transfor- mations that determined profound changes in the geomorphology, position of the shoreline, terrestrial and coastal ecosystems of the region. The study of palaeoclimatic conditions during the last 15,000 years provides the elements to understand the history and evolution of terrestrial and marine ecosystems, their dynamics and ability to react to 
the climate change. The analysis of palynological organic matter preserved in the sedimentary records has special interest given its importance and potential for the palaeoenvironmental and palaeoclimatic assessment (Candel et al., 2013). The palynofacies analysis comprises the study of the total palynological organic matter (palynomorphs plus other organic matter) and contributes to the understanding of marine transgressive-regressive sedimentary cycles. The relationship between the source material (continental or marine), and the size and diversity provides information on the hydrodynamics and ecology of the depositional environment (Candel et al., 2013). The conventional palynological analysis considers the content of palynomorphs (pollen, spores, and organic-walled microplankton) present in a paIynological preparation. The study of fossil pollen records provides evidence for the reconstruction of vegetation com-

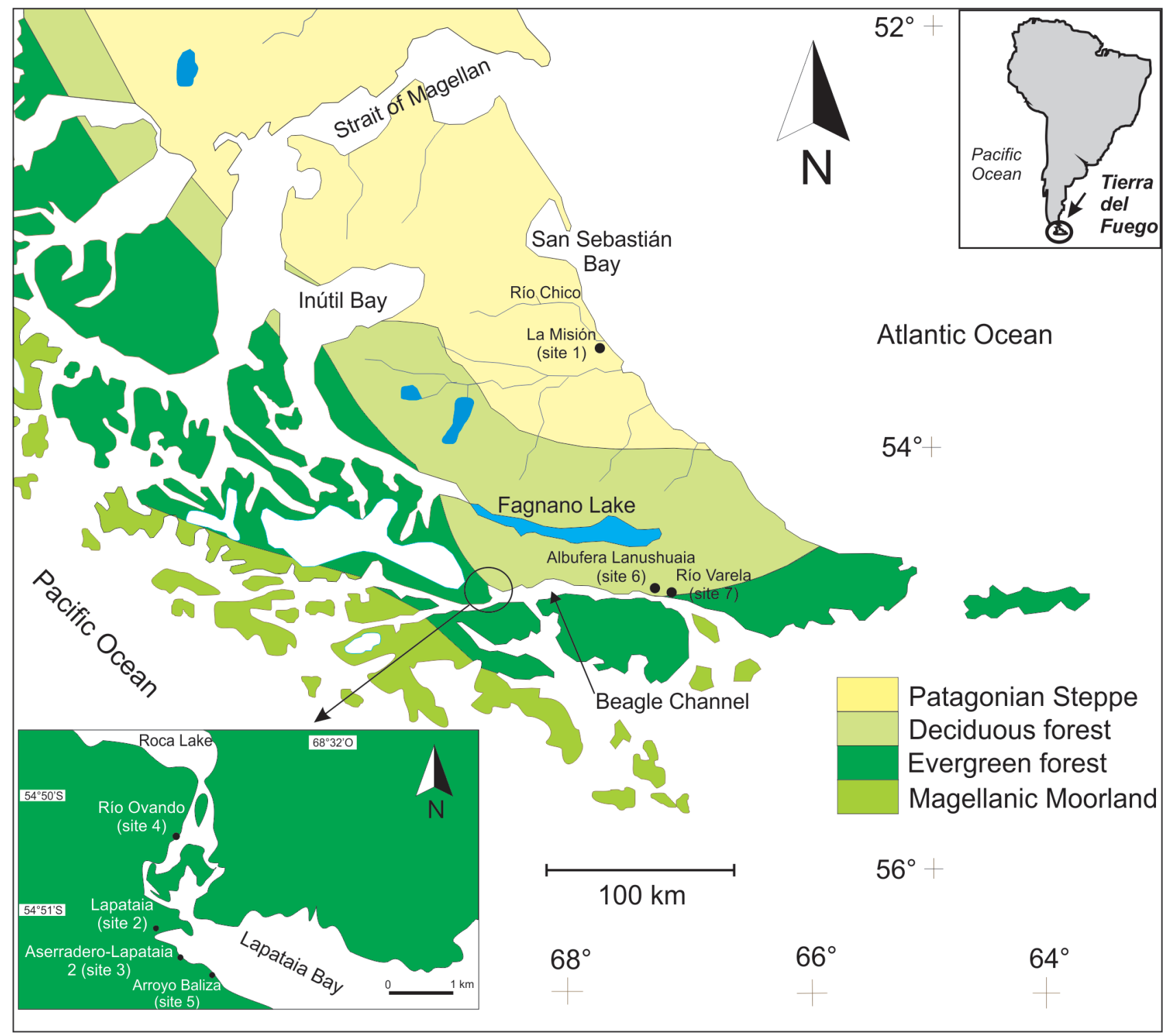

Figure 1. Vegetation map of Isla Grande de Tierra del Fuego showing the localities mentioned in the text, the vegetational units and mean annual precipitation (mm) (modified after Tuhkanen, 1992). 1, La Misión; 2, Lapataia; 3, Aserradero-Lapataia 2; 4, Río Ovando; 5, Arroyo Baliza; 6, Albufera Lanushuaia; 7, Río Varela. 
munities and infers the changes that occurred in these communities at spatial and temporal scales in response to environmental and climatic variations. Also, the study of marine organic-walled palaeomicroplankton (mainly dinoflagellate cysts and acritarchs) has a special interest for palaeoenvironmental assessment and palaeoclimatic inferences. Numerous studies have shown the existence of a close relationship between the distribution of dinoflagellate cyst (dinocyst) assemblages and the physico-chemical conditions of seawater such as sea-surface temperature, seasurface salinity, nutrient availability, primary productivity and seasonality and extent of the sea ice cover (de Vernal et al., 2001, 2013; Radi and de Vernal, 2008). The variations in their records are interpreted in terms of oceanographic and atmospheric changes.

Many studies of Late Quaternary palaeoecological conditions from Isla Grande de Tierra del Fuego, southernmost Patagonia, were largely based on palynological records from terrestrial sediments (Heusser and Rabassa, 1987, 1995; Heusser, 1989, 1998, 2003; Markgraf, 1993; Borromei,
1995; Quattrocchio and Borromei, 1998; Mauquoy et al., 2004; Borromei et al., 2007, 2010, 2014; Borromei and Quattrocchio, 2008; Markgraf and Huber, 2010; Musotto, 2013; Waldmann et al., 2014; Musotto et al., 2016a, in press; among others works). Studies on dinocyst assemblages and palynofacies from Late Quaternary deposits of the southern South America are still limited to a few contributions (Borromei and Quattrocchio, 2001, 2007; Grill et al., 2002; Candel et al., 2009, 2011, 2012, 2013, in press; Rabassa et al., 2009; Candel, 2010; Candel and Borromei, 2013; Fernández et al., 2014).

The present contribution is a compilation of pollen, microplankton, and palynofacies datasets from Holocene radiocarbon-dated marine deposits located in Tierra del Fuego (Tab. 1). Palaeocommunities and palaeoenvironments during the Holocene marine ingression into the Beagle Channel were interpreted from the palynological and palynofacies analyses of material mostly recovered from sites located on the northern coast of the channel. The terrace system that characterise this marine incursion into the Beagle Channel

TABLE 1. Selected Late Quaternary marine deposits from Isla Grande de Tierra del Fuego $\left(53-55^{\circ} \mathrm{S}\right)$. The palynological sites are listed according to their location on the Atlantic coast and the northern coast of the Beagle Channel, from west to east sectors.

\begin{tabular}{|c|c|c|c|c|}
\hline Site No. & Site name & Latitude (S) & Longitude (W) & References \\
\hline \multicolumn{5}{|l|}{ Atlantic coast } \\
\hline 1 & La Misión & $53^{\circ} 30^{\prime}$ & $67^{\circ} 50^{\prime}$ & Markgraf (1980, 1993) \\
\hline \multicolumn{5}{|c|}{ North coast of Beagle Channel } \\
\hline 2 & Bahía Lapataia & $54^{\circ} 50^{\prime}$ & $68^{\circ} 34^{\prime}$ & $\begin{array}{l}\text { Borromei and Quattrocchio } \\
(2001,2007)\end{array}$ \\
\hline 3 & Aserradero-Lapataia2 & $54^{\circ} 51^{\prime}$ & $68^{\circ} 34^{\prime}$ & $\begin{array}{l}\text { Rabassa et al. (2009); } \\
\text { Candel and Louwye (2015) }\end{array}$ \\
\hline 4 & Río Ovando & $54^{\circ} 51^{\prime}$ & $68^{\circ} 35^{\prime}$ & Candel et al. (2009) \\
\hline 5 & Arroyo Baliza & $54^{\circ} 51^{\prime}$ & $68^{\circ} 33^{\prime}$ & Candel et al. in press \\
\hline 6 & Albufera Lanushuaia & $54^{\circ} 52^{\prime}$ & $67^{\circ} 60^{\prime}$ & Candel et al. (2011) \\
\hline 7 & Río Varela & $54^{\circ} 52^{\prime}$ & $67^{\circ} 11^{\prime}$ & Grill et al. (2002) \\
\hline
\end{tabular}


provides evidence for different temporal windows contributing significantly to the understanding of the palaeoenvironmental response to Holocene climate variability. Conventional radiocarbon ages of marine sediments belonging to own studies were converted to calibrated ${ }^{14} \mathrm{C}$ ages by the program Calib 7.1 (Stuiver et al., 2015) using the Marine13 calibration data set (Reimer et al., 2013). A local ${ }^{14} \mathrm{C}$ marine reservoir effect $(\Delta R)$ value for the study region of $221 \pm 40$ years should be taken into consideration (Gordillo et al., 2015). The published radiocarbon dates corresponding to marine environments and carried out by different authors have been maintained as ${ }^{14} \mathrm{C}$ ages.

\section{GEOGRAPHICAL SETTING}

Isla Grande de Tierra del Fuego is the largest island of the Fuegian Archipelago and is located at the southernmost end of South America between latitude $53-55^{\circ} \mathrm{S}$ and longitude $66-74^{\circ} \mathrm{W}$ (Fig. 1). It is the highest latitude landmass in the Southern Hemisphere outside Antarctica and is strongly influenced by the climatic conditions of the Southern Ocean and the Antarctic Peninsula. Its separation from continental South America was a result of marine flooding of deep glacial valleys during the Holocene (Rabassa et al., 2011). The Beagle Channel forms a connection between the Atlantic Ocean and the Pacific Ocean in the southernmost Argentinian coast of Tierra del Fuego. It is a former tectonic valley that extends over $220 \mathrm{~km}$ from west to east and was completely covered by ice during the Last Glacial Maximum (LGM) ca. 25 ka ago (Rabassa, 2008). Following deglaciation, the depressed areas were occupied by proglacial lakes and glaciofluvial and glaciolacustrine environments until the valley was flooding by seawater (Rabassa et al., 1986). The Beagle Channel opened before 8,200 ${ }^{14} \mathrm{C}$ yr BP and the lake water was replaced by seawater. The Holocene transgression is recorded at several sites along the Patagonian coast reaching a maximum sea-level between 6,500 and 4,000 yr BP (Codignotto et al., 1992). According Flemming et al. (1998), during the period 9,500 to $7,000 \mathrm{yr}$ BP the postglacial sea-level suffered a sharp rise from $-24 \mathrm{~m}$ to $-3 \mathrm{~m}$ indicating an uplift rate of $0.084 \mathrm{~m} / \mathrm{yr}$. The global scale of sea level rise would have accelerated around $0.428 \mathrm{~m} / \mathrm{yr}$ from 7,000 BP until reach the current level.

The channel was submerged by the sea and the entire area turned into a fjord by $7,900{ }^{14} \mathrm{C}$ yr BP (Rabassa et al., 1986) leaving marine deposits, mostly raised beaches, distributed along both the northern and southern Beagle Channel coasts (Gordillo, 1993). These deposits are mostly sandy and gravely in grain-size, although clay-like sediments are recorded mainly in the westernmost sector of the Beagle Channel. The origin of these raised beaches appears related to tectonic uplift and/or isostatic recovery following deglaciation (Rabassa et al., 2000; Bujalesky et al., 2004).

Conversely, the Atlantic coast was ice-free during the LGM (Rabassa et al., 2000). The distinctive characteristic of the Holocene littoral deposits at the northern Atlantic coast (Bahía San Sebastián and Río Chico area) is the presence of regressive-like sequences at protected areas, while transgressive-like beach facies have developed at exposed areas (Rabassa et al., 2000, p. 227). The dissimilarities in geomorphological and evolutionary trends of these littoral deposits of the northeastern Atlantic coast occurred as a consequence of the underlying palaeorelief that was dipping northwards and carved during the Pleistocene glaciations (Rabassa et al., 2000). The comparison of the Holocene raised beaches between the northern Atlantic coast of Tierra del Fuego (La Misión, Río Chico, Bahía San Sebastián) (Fig. 1) and the northwestern coast of Beagle Channel (Punta Pingüinos, Bahía Golondrina, Playa Larga) (Fig. 2), indicate that these dissimilarities may partially be the result of differential tectonic uplifting rates (Rabassa et al., 2000). The tectonic uplift during the last $8,000 \mathrm{yr}$ was greatest at the western Beagle Channel (approximately $1.2+0.2 \mathrm{~mm} / \mathrm{yr}$ ), diminishing northward and eastward. It seems to be negligible toward the northern coast of Isla Grande. The glacioisostatic rebound at the Beagle Channel seems to have operated only during deglaciation or in 1-2 millennia after the final ice recession (Isla and Bujalesky, 2008).

\section{MODERN CLIMATE AND VEGETATION}

The climate of Tierra del Fuego is cold-temperate and is influenced predominantly by the seasonal shifts of the Polar Front and the cyclonic activity related to the southern westerlies (Pisano, 1977). It is highly oceanic in the western and southern parts of the archipelago and increasingly continental towards the east and north. Mean summer isotherms increase northeastward from 9 to $12^{\circ} \mathrm{C}$. The pre- 
cipitation decreases to the north and east. The mean annual rainfall in Ushuaia is $570 \mathrm{~mm}$ and less than $300 \mathrm{~mm}$ in Río Grande to the north (Prohaska, 1976). The modern vegetation corresponds to the Fuego-Patagonian Steppe in the north, followed southward successively by the Subantarctic Deciduous Beech Forest and the Evergreen Beech Forest (Fig. 1). They are characterized by three species of southern beech, Nothofagus pumilio (Poeppig and Endl.) Krasser 1896 (lenga), N. antarctica (Forster f.) Oersted 1871 (ñire), and N. betuloides (Mirbel) Oersted 1871 (guindo), which grow to an average altitudinal limit of 550-600 m a.s.l. (meters above sea level) and predominate where precipitation exceeds $400 \mathrm{~mm} \mathrm{yr}^{-1}$. Magellanic Moorland occurs beyond the forest along the exposed outermost coast under conditions of increased precipitation, wind and poor drainage. High Andean Desert vegetation develops above the treeline (600 m a.s.I.) in the Fuegian Andes until the snowline is reached (Tuhkanen, 1992).

\section{SURFACE SEDIMENTS SAMPLES AS MODERN ANA- LOGUES}

Palynological and palynofacies analyses of surface sediments from the Beagle Channel (Fig. 2) were carried out to establish modern analogues for comparison with other Holocene marine records in southern Tierra del Fuego. The results showed the predominance of Nothofagus dombeyitype pollen indicating the presence of forest communities in the coastal area (Candel et al., 2013). The aquatic palynomorph assemblages, mainly dinoflagellate cysts, are dominated by Peridiniales over Gonyaulacales taxa (Candel et al., 2012, 2013). The assemblages (Tab. 2) were mostly composed by Protoperidiniaceae such as Brigantedinium spp., Echinidinium spp., and Selenopemphix quanta (Bradford 1975) Matsuoka 1985, typical of a marginal marine and surface waters characterized by low to moderate salinity, and high nutrient input by rivers. These assemblages were thus compatible with the occurrence of freshwater to brackish water taxa (Botryococcus braunii Kützing 1849, Botryococcus sp., Polyasterias sp., Halodinium sp., and Radiosperma corbiferum Meunier 1910). The assemblages from the Beagle Channel showed similarities with those of high latitude regions of the Northern Hemisphere (Candel et al., 2012).

The palynofacies showed the dominance of highly degraded translucent phytoclasts associated with amorphous organic matter (AOM) and palynomorphs, while opaque phytoclasts were poorly represented. The organic constituents indicated the proximity of a continental source area to the marine environment, with distances and/or times of relatively short transport. The predominance of translucent phytoclasts associated with pyrite suggested reducing conditions, probably associated with marginal-marine environments. The high terrestrial organic matter input into the depositional area was consistent with these coastal environments. A comparison with the sections of Holocene age (Río Varela, Aserradero-Lapataia, Arroyo Baliza, Río Ovando, and Albufera Lanushuaia) (Fig. 1) showed similar distribution of the total palynological matter (Grill et al., 2002; Rabassa et al., 2009; Candel et al., 2011, 2013).

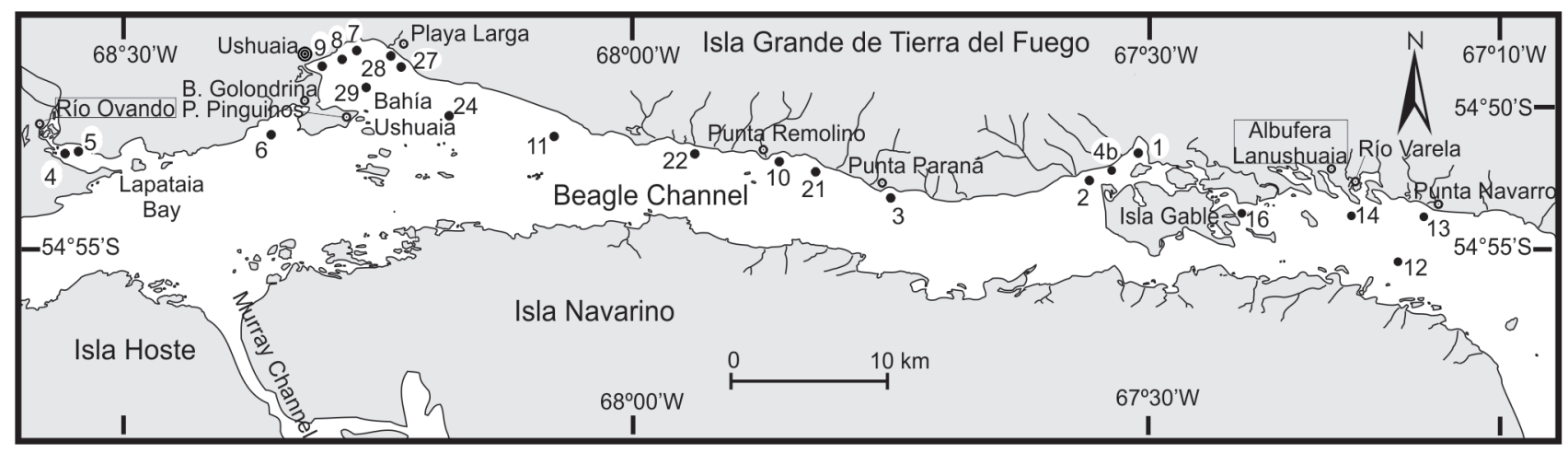

Figure 2. Detailed map of the Beagle Channel region and location of the surface sediment samples. 
TABLE 2. Aquatic palynomorphs identified in surface sediments from the Beagle Channel area (modified after Candel et al., 2012). BL, Bahía Lapataia; BG, Bahía Golondrina; BU, Bahía Ushuaia; PR, Punta Remolino; PP, Punta Paraná; IG, Isla Gable; EIG, External Isla Gable.

\begin{tabular}{|c|c|c|c|}
\hline Sector & WESTERN & CENTRAL & EASTERN \\
\hline Sampling sites & $B L, B G, B U$ & $P R, P P$ & $I G, E I G$ \\
\hline \multicolumn{4}{|l|}{ Dinocysts } \\
\hline Brigantedinium cariacoense (Wall 1967) Lentin and Williams 1993 & & $x$ & $\mathrm{x}$ \\
\hline Brigantedinium simplex Wall 1965 ex Lentin and Williams 1993 & $x$ & $\mathrm{x}$ & $\mathrm{x}$ \\
\hline Brigantedinium spp. & $x$ & $\mathrm{x}$ & $\mathrm{x}$ \\
\hline Dinocyst sp. 1 & $x$ & $x$ & $\mathrm{x}$ \\
\hline Dubridinium cf. D. sp. Reid 1977 & $\mathrm{x}$ & & $\mathrm{x}$ \\
\hline Echinidinium cf. E. delicatum Zonneveld 1997 & $x$ & $x$ & $x$ \\
\hline Echinidinium granulatum Zonneveld 1997 & $x$ & $x$ & $x$ \\
\hline Echinidinium cf. E. granulatum Zonneveld 1997 & $\mathrm{x}$ & $\mathrm{x}$ & $\mathrm{x}$ \\
\hline Echinidinium spp. & $\mathrm{x}$ & $\mathrm{x}$ & $\mathrm{x}$ \\
\hline Islandinium? cezare (de Vernal et al. 1989 ex de Vernal in Rochon et al. 1999) Head et al. 2001 & $x$ & $x$ & $x$ \\
\hline Islandinium minutum (Harland and Reid in Harland et al. 1980) Head et al. 2001 & $x$ & $x$ & $x$ \\
\hline Pentapharsodinium dalei Indelicato and Loeblich III 1986 & $\mathrm{x}$ & $x$ & $\mathrm{x}$ \\
\hline Polykrikos kofoidii Chatton 1914 & $x$ & $x$ & $x$ \\
\hline Polykrikos schwartzii Bütschli 1873 & $x$ & $x$ & $x$ \\
\hline Protoperidinioids & $x$ & $x$ & $x$ \\
\hline Quinquecuspis concreta (Reid 1977) Harland 1977 & $x$ & $x$ & $x$ \\
\hline Selenopemphix nephroides (Benedek 1972) Benedek and Sarjeant 1981 & $x$ & $x$ & $x$ \\
\hline Selenopemphix quanta (Bradford 1975) Matsuoka 1985 & $x$ & $x$ & $x$ \\
\hline Selenopemphix cf. S. quanta (Bradford 1975) Matsuoka 1985 & $\mathrm{x}$ & $x$ & $\mathrm{x}$ \\
\hline Spiniferites lazus Reid 1974 & $x$ & & \\
\hline Spiniferites ramosus (Ehrenberg 1838) Mantell 1854 sensu lato & $\mathrm{x}$ & $x$ & $\mathrm{x}$ \\
\hline Spiniferites cf. S. mirabilis (Rossignol 1964) Sarjeant 1970 & & & $x$ \\
\hline Spiniferites $s p$. & $x$ & & \\
\hline Spiniferites spp. & $\mathrm{x}$ & $\mathrm{x}$ & $\mathrm{x}$ \\
\hline Trinovantedinium cf. T. applanatum (Bradford 1977) Bujak and Davies 1983 & $\mathrm{x}$ & $\mathrm{x}$ & \\
\hline Votadinium calvum Reid 1977 & $x$ & $\mathrm{x}$ & $\mathrm{x}$ \\
\hline Votadinium spinosum Reid 1977 & $x$ & $x$ & $x$ \\
\hline Dinocyst species diversity & 17 & 16 & 17 \\
\hline \multicolumn{4}{|l|}{ Acritarchs } \\
\hline Acritarch sp. 1 & & $\mathrm{x}$ & $\mathrm{x}$ \\
\hline Acritarch sp. 2 & & $x$ & \\
\hline Cyclopsiella sp. & & $x$ & \\
\hline Halodinium $s p$. & $x$ & $x$ & $x$ \\
\hline \multicolumn{4}{|l|}{ Zoomorphs } \\
\hline Copepod eggs & $\mathrm{x}$ & $x$ & $x$ \\
\hline Foraminiferal linings & $x$ & $x$ & $x$ \\
\hline \multicolumn{4}{|l|}{ Other algae } \\
\hline Botryococcus braunii Kützing 1849 & $x$ & & \\
\hline Botryococcus $s p$. & $x$ & $x$ & $x$ \\
\hline Zygnemataceae & $x$ & & $x$ \\
\hline Spirogyra $s p$. & & $x$ & \\
\hline Tasmanaceae & $x$ & & \\
\hline Radiosperma corbiferum Meunier 1910 & $x$ & $x$ & $x$ \\
\hline Polyasterias $s p$. & $x$ & $x$ & $x$ \\
\hline Other aquatic palynomorphs diversity & 8 & 10 & 8 \\
\hline
\end{tabular}


PALAEOENVIRONMENTS AND PALAEOCLIMATIC RECONSTRUCTION DURING THE HOLOCENE TRANSGRESSION IN TIERRA DEL FUEGO

\section{Holocene times}

The Early Holocene after 11,500 cal yr BP was characterized by a significant increase in temperature coinciding with the onset of the Antarctic Climate Optimum (Bentley et al., 2009). The increasing temperature and lower levels of effective moisture than today would have favored the establishment of an open Nothofagus woodland in southern Tierra del Fuego (Beagle Channel area), with high fire frequency (Heusser, 1998; Markgraf and Huber, 2010); while steppe environments remained in central Tierra del Fuego (Fagnano Lake area) until ca. 9,500 cal yr BP (Musotto et al., 2016a). Nowadays, a similar pattern of vegetation belonging to the steppe/forest ecotone and steppe is observed in the central and north sector of the island, respectively, with precipitations less than $500 \mathrm{~mm} \mathrm{yr}^{-1}$ and summer temperature between $11-12{ }^{\circ} \mathrm{C}$ (Tuhkanen, 1992). This climatic scenario could have been induced by the migration of the westerlies winds toward higher latitudes, reduced Antarctic ice sheet and decrease of the thermal gradient between the poles and Ecuador (Markgraf and Huber, 2010).

This warm period was coincident with a transgressive event in Tierra del Fuego. The oldest marine levels identified into the Beagle Channel are located in the western sector: Bahía Lapataia (site 2, Fig. 1) at 8,478 cal yr BP (Rabassa et al., 1986), Aserradero-Lapataia 2 (site 3, Fig. 1) at 8,408 cal yr BP (Rabassa et al., 2009), and Lago Roca (Fig. 1) at 7,760 cal yr BP (Gordillo et al., 1993). The ingression of marine waters generated deep and narrow fjords with complex archipelagos (Gordillo et al., 1993). The Lago Roca-Lapataia area was a low energy, freshwater estuarine environment. The recorded mollusk association is represented by epibenthic taxa (mytilids and cirripeds) tolerant of estuarine conditions (Gordillo et al., 1993; Gordillo, 1999). According with the mollusk assemblages, around $7,500{ }^{14} \mathrm{C} \mathrm{yr} \mathrm{BP}$, the whole area turned into a fjord and Río Ovando (site 4, Fig. 1) and Lago Roca sites became in shallow-marine environments (Gordillo et al., 2005). The mollusk assemblages indicate that the northern coast of the Beagle Channel was occupied by shallow benthic palaeocommunities during the Holocene (Gordillo, 1999; Gordillo et al., 2005). Postglacial mollusk assemblages from the Beagle Channel are similar to current mollusk associations living in the region. Therefore, it was inferred that the climatic conditions remained stable enough to allow the development of these marine faunal associations with a wide ecological range (Gordillo, 1999).

In the northeastern Atlantic coast at the La Misión locality (site 1, Figs. 1 and 7), a sediment core located circa 3.5 $\mathrm{km}$ from the present shore, holds marine sediments dated between $8,720{ }^{14} \mathrm{C}$ yr BP and $270{ }^{14} \mathrm{C}$ yr BP (Markgraf, 1983, 1993). Changes in Chenopodiaceae pollen, diatoms and ostracodes provided a history of the sea-level variation. The marine sediments are clays with high percentages of Chenopodiaceae pollen and an abundance of diatom and ostracode taxa with brackish to coastal marine affinities (Markgraf, 1980, 1993). During the marine transgression, the vegetation was represented by a relatively open Nothofagus forest at $c a .8,000{ }^{14} \mathrm{C}$ yr BP. This forest environment continued with only minor changes until after $1,000{ }^{14} \mathrm{C}$ yr ago, when the steppe expanded again (Markgraf, 1993).

\section{Early to Mid-Holocene marine palynomorph assemblages}

Between ca. 8,200 and 5,500 cal yr BP the palynological analysis showed for the Bahía Lapataia locality in western the Beagle Channel (site 2, Figs. 3 and 7) the presence of marginal-marine environments with a predominance of terrestrial palynomorphs over marine palynomorphs indicating an important freshwater input. Two relatively higher sea levels were identified by the increased abundance of marine palynomorphs; the first was observed between 8,478 cal yr BP and the second after 5,978 cal yr BP (Borromei and Quattrocchio, 2007). The marine palynomorphs were characterized by a poor dinoflagellate cyst assemblage dominated by Peridiniales taxa (Brigantedinium spp. and Selenopemphix sp.) over Gonyaulacales taxa (Spiniferites spp. and Operculodinium centrocarpum Deflandre and Cookson 1955 sensu Wall 1967) (Fig. 6). The acritarch Halodinium sp. and zoomorphs, such as foraminiferal linings and copepod eggs, were abundant. This marine palynomorph assemblage reflects an inner estuarine environment with low and variable salinities and/or turbulence, cool-temperate sea water temperature and abundance of dissolved nutrients caused by freshwater runoff (Borromei and Quattrocchio, 2001, 
2007). Likewise, the palynological record from AserraderoLapataia 2 (site 3) showed at 8,408 cal yr BP a dominance of arboreal Nothofagus pollen associated with shrubs and herbs. The aquatic palynomorph assemblage consisted of dinoflagellate cysts (mainly Brigantedinium simplex Wall 1965 ex Lentin and Williams 1993, Echinidinium granulatum Zonneveld 1997, Selenopemphix quanta, Polykrikos schwartzii Bütschli 1873, among others) which showed an increasing diversification from the middle to upper part of the section, acritarchs (Halodinium sp., Palaeostomocystis fritilla Bujak 1984, and P. subtilitheca Roncaglia 2004), foraminiferal linings, copepod eggs and freshwater to brackish-marine algae (Candel and Louwye, 2015). The low dinoflagellate cyst species diversity could indicate the development of low-salinity environments affected by glacier meltwater discharge. These environments persisted at least several years, as the influence of seawater was expanding by global eustatic rise (Candel and Louwye, 2015).

\section{Early to Mid- Holocene}

\section{Closed-canopy Nothofagus forest}

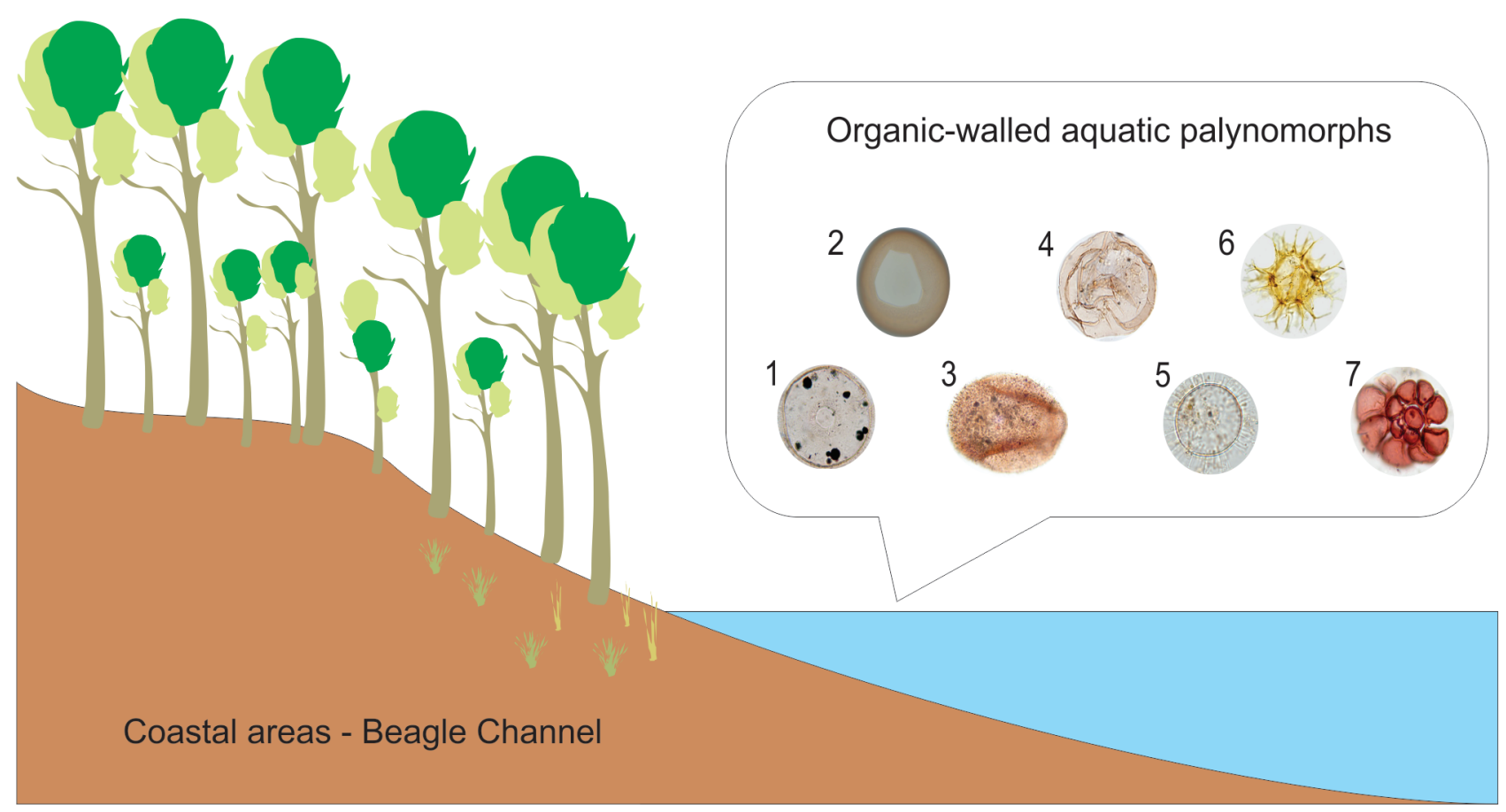

Palynological studied sites:

Bahía Lapataia $(8,478-5,978$ cal yr BP)

Aserradero-Lapataia 2 (8,408 cal yr BP)

Río Varela $(6,440$ - 6,256 cal yr BP)
Organic-walled aquatic palynomorphs assemblage:

1- Halodinium sp.

2- Brigantedinium spp.

3- Copepod egg

4- Selenopemphix nephroides

5- Operculodinium centrocarpum

6- Spiniferites sp.

7- Foraminiferal lining

Figure 3. Evolutionary coastal model during the Early and Mid-Holocene of the Beagle Channel. 
East of Beagle Channel, more precisely at Río Varela locality (site 7, Figs. 1, 3 and 7) 100 km to the east of Bahía Lapataia site, two marine levels were identified. The first level was recorded at the base of the sequence at 6,440 cal yr BP (Units 1-2: $1.60 \mathrm{~m}$ depth), and the other marine level at 6,256 cal yr BP (Unit 4: 1.27 m depth) (Grill et al., 2002). Unit 1 holds a microplankton assemblage constituted by Protoperidiniaceae dinocysts (Brigantedinium spp. and Selenopemphix nephroides (Benedek 1972) Benedek and Sarjeant, 1981), the acritarch Halodinium sp., copepod eggs and foraminiferal linings. These palynomorphs indicated a nearshore and low-energy environment with high nutrients supply, low salinity and cooler sea water temperature. In Unit 2 the record of Gonyaulacales dinocysts (Spiniferites sp. and Operculodinium centrocarpum; Fig. 6), accompanied with a decrease in Halodinium sp. and zoomorphs, suggested external neritic-marine conditions. Towards 6,256 cal yr BP (Unit 4) the presence of heterotrophic dinocysts (Brigantedinium spp. and Selenopemphix nephroides), Halodinium sp., and foraminiferal linings indicating a marine environment with nutrient-rich waters, variable salinity and high fluvial input (Grill et al., 2002). The organic matter content in sediments from Río Varela was mainly characterized by amorphous organic matter (AOM) related to degraded plankton and associated with pyrite, indicating anoxic marine conditions (Grill et al., 2002).

The pollen records revealed in coastal areas, prior to the transgressive event, the development of the forest-steppe ecotone in concordance with the regional vegetational pattern (Borromei and Quattrocchio, 2008). However, at the time of the marine incursion the coastal vegetation in the Beagle Channel area was mainly arboreal characterised by a significant increase in Nothofagus pollen, suggesting high effective moisture due to the moderating action of the sea (Grill et al., 2002; Borromei and Quattrocchio, 2007, 2008).

\section{Middle to Late Holocene marine palynomorph assem- blages}

The climate changed towards colder and wetter conditions after ca. 6,000 cal yr BP, and favored the regional expansion of a closed-canopy Nothofagus forest, the replacement of minerotrophic fens to ombrotrophic Sphagnum bogs, and the decrease in fire activity (Heusser, 2003; Mark- graf and Huber, 2010; Musotto et al., 2016a, in press). In coastal areas, significant percentages of Nothofagus pollen recorded throughout the profiles suggested the presence of a closed-canopy forest, confirming the existence of a cool and wet climate (Candel et al., 2009, in press). These climatic conditions could be related with the increased strength and enhanced seasonal cycle of the westerlies (Markgraf and Huber, 2010).

Low concentration and diversity of dinocysts (9 identified taxa) were recorded in the eastern sector of Beagle Channel, at Albufera Lanushuaia (site 6, Figs. 1, 4 and 7). Between 5,916 cal yr BP and 5,713 cal yr BP, the dinocysts assemblage showed low diversity species (Brigantedinium spp., Echinidinium spp., Islandinium minutum (Harland and Reid in Harland et al., 1998) Head et al. 2001, Dubridinium sp. Reid 1977, Selenopemphix nephroides, round brown cysts, and indeterminate proximochorate dinocysts) suggested a marginal-marine environment with low to moderate salinity and high nutrients concentration in the surface waters, probably due to the contribution of freshwater runoff. After 5,713 cal yr BP, a slight increase in species diversity and a decrease in the concentration of the dinocysts were observed. The assemblage included Brigantedinium spp., Echinidinium spp., Selenopemphix quanta, Selenopemphix cf. S. quanta, Votadinium spinosum Reid 1977, Polykrikos kofoidii Chatton 1914, Polykrikos schwartzii, round brown cysts, and indeterminate proximochorate dinocysts (Fig. 6). The assemblage suggested environmental conditions similar to the beginning of this sedimentary sequence. However, the presence of species such as $P$. kofoidii, P. schwartzii, and V. spinosum could indicate a marine environment with normal salinity above 30 psu (Candel, 2010; Candel et al., 2011). The palynofacies analysis showed a dominance of translucent phytoclasts accompanied by amorphous organic matter and palynomorphs. Thus, the organic constituents indicated the proximity of a continental source to the marine environment, with relatively short distances and/or times of transport. The predominance of translucent phytoclasts associated with pyrite suggested reducing conditions, probably related to marginal-marine environments (Candel et al., 2011).

At the western sector of the Beagle Channel, the palynological analysis of Río Ovando (site 4, Figs. 4, 7) showed 
the dominance of terrestrial (pollen grains and spores) over aquatic palynomorphs (dinocysts, acritarchs, foraminiferal linings, copepod eggs and other algae) during the Middle
Holocene. Towards 3,929 cal yr BP, a relatively high species diversity of 10 identified taxa and a low concentration of dinocysts were recorded. The identified dinocysts assem-

\section{Middle to Late- Holocene}

Closed-canopy Nothofagus forest

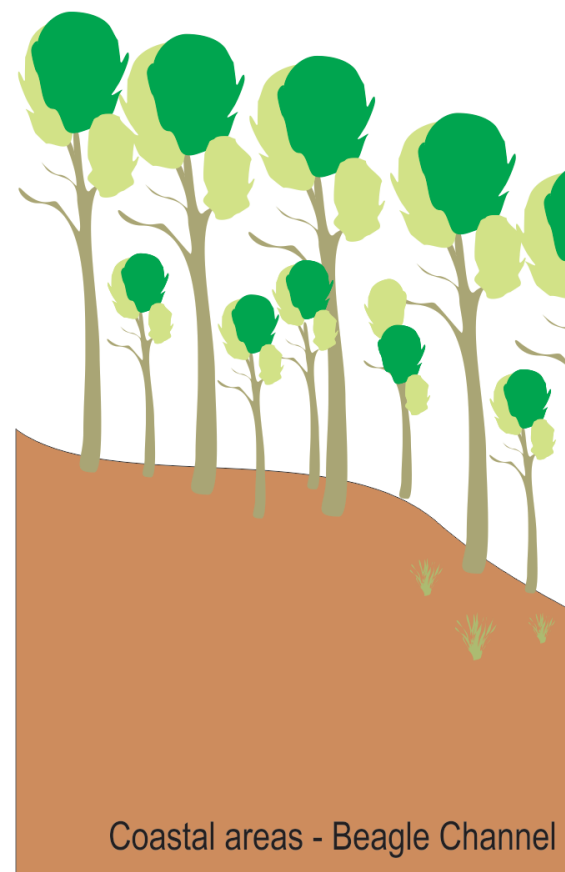

\section{Palynological studied sites:}

Albufera Lanushuaia: $6,000-5,713$ cal yr BP Río Ovando: 3,929 - 3,797 cal yr BP Arroyo Baliza: 3,499 - 2,595 cal yr BP

\section{Particulate organic matter constituents:}

A-B. Palynofacies with detail of biostructure translucent phytoclasts (BPh) and nonbiostructure translucent phytoclasts $(\mathrm{nBPh})$, palynomorphs (Pollen) and pyrite (Py) . C-D. Palynofacies with detail of nonbiostructure translucent phytoclasts $(\mathrm{nBPh})$, amorphous organic matter (AOM) and dinocysts (D).
Organic-walled aquatic palynomorphs assemblage:

1- Halodinium sp.

2-Brigantedinium spp.

3-Copepod egg

4- Islandinium minutum

5-Echinidinium granulatum

6-Selenopemphix quanta

7- Votadinium spinosum

8-Selenopemphix nephroides

9- Polykrikos schwartzii

10- Operculodinium cf. O. centrocarpum

11- Foraminiferal lining

12-Spiniferites sp.

Figure 4. Evolutionary coastal model during the Middle and Late Holocene of the Beagle Channel. 
blage (Islandinium minutum, Islandinium cf. I. minutum, Echinidinium spp., accompanied by Brigantedinium spp., Polykrikos kofoidii, Polykrikos schwartzii, Operculodinium cf. O. centro- carpum, and Selenopemphix quanta) (Fig. 6) suggested a marginal-marine environment with low to moderate salinity and high concentrations of nutrients in the sea surface waters,

\section{Late Holocene (last 1000 years)}

Open Nothofagus forest with areas of grasslands and shrubs

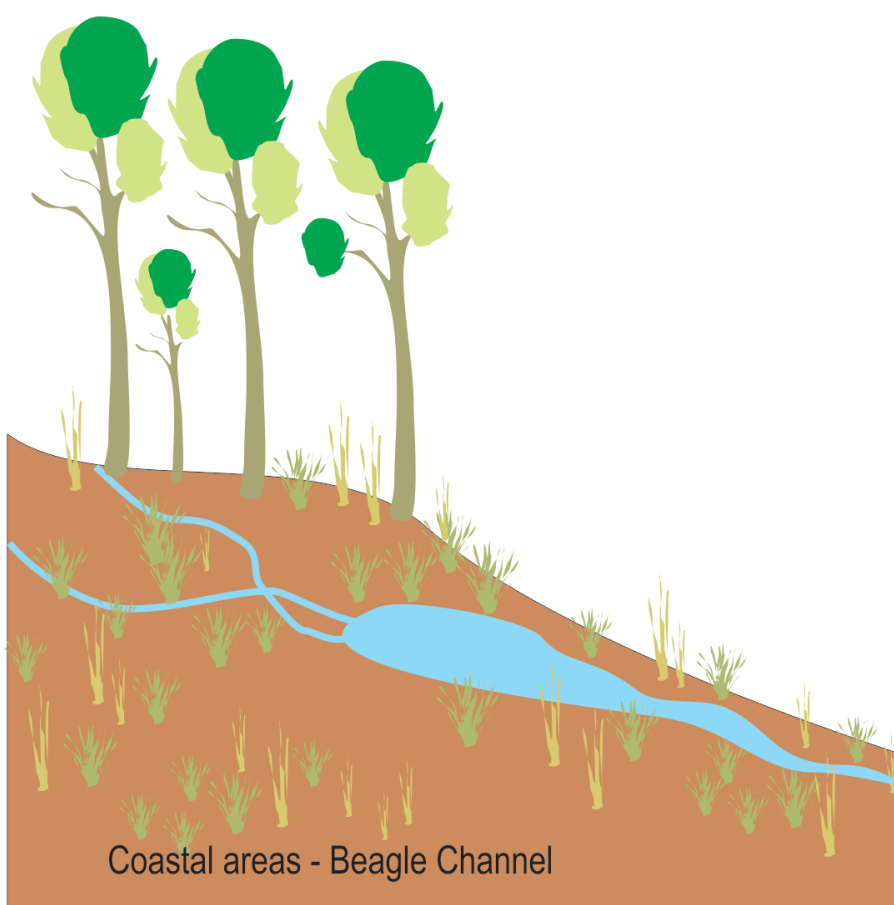

Palynofacies
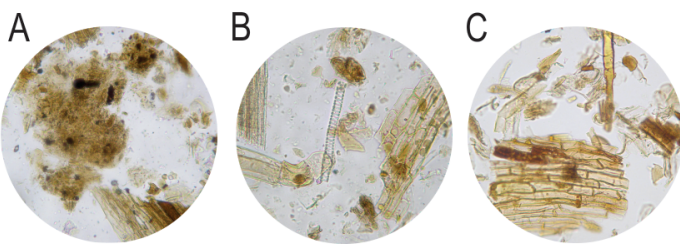

Organic-walled aquatic palynomorphs
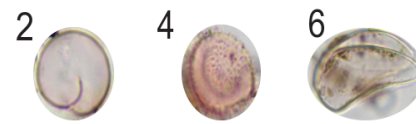

8
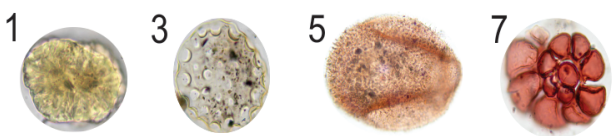

\section{Palynological studied sites:}

Río Ovando: after 3,797 cal yr BP (Palynological Zone RO-1, Candel et al., 2009)

Albufera Lanushuaia: after 1,958 cal yr AD (Palynological Zone AL-1, Candel et al., 2011)
Organic-walled aquatic palynomorphs assemblage:

1. Botryococcus sp.

2. Sigmopollis sp.

3. Zygnema sp.

4. 181 type (van Geel)

5. Copepod egg

6. Spirogyra sp.

7. Foraminiferal lining

8. Cymatiosphaera sp.

\section{Particulate organic matter constituents:}

A. Palynofacies with detail of biostructure translucent phytoclasts (Bph) and non-biostructure translucent phytoclasts (nBPh), together with amorphous organic matter (AOM).

B. Palynofacies detail (FtB) of biostructure translucent phytoclasts $(\mathrm{Bph})$ and non-biostructure translucent phytoclasts (nBPh).

C. Palynofacies biostructure translucent phytoclasts (Bph).

Figure 5. Evolutionary coastal model during the last 1,000 years of the Beagle Channel. 

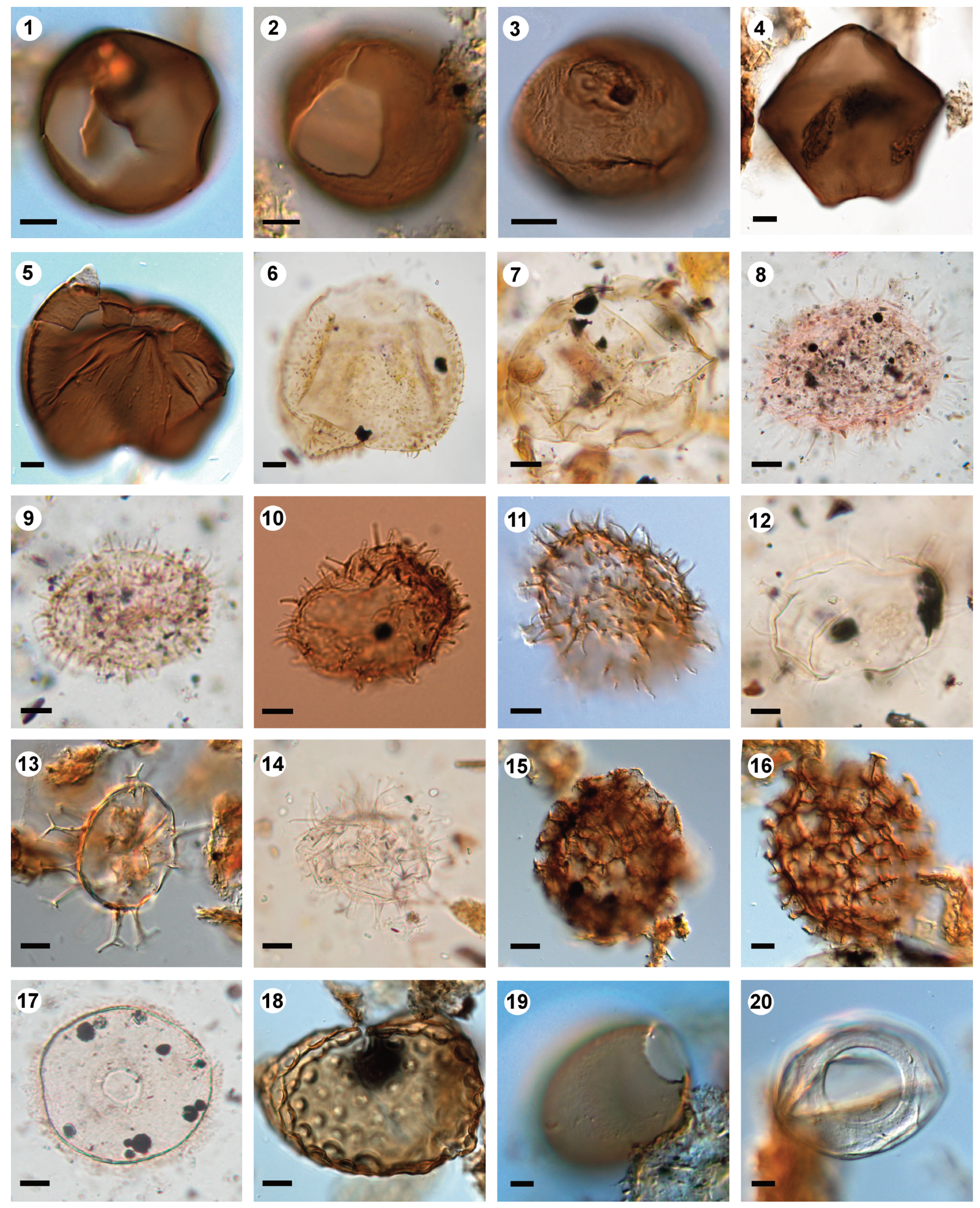
probably due to the contribution of freshwater by runoff (Candel, 2010). This diversification of species was also supported by data from mollusks confirming that during this period a major expansion took place of the fauna through a diversification of mollusk assemblages characterized by Tawera gayi, Venus antiqua, Hiatella solida, Trophon geversianus, Xymenopsis muriciformis, Pareuthria plumbea, Laevilitorina, Neolepton, Carditella naviformis, and Cyclocardia compresa. This indicates a change to present-day conditions. Most of these species could have survived the neoglacial episodes (Gordillo et al., 2005). A dinocysts assemblage dominated exclusively by Islandinium-Echinidinium complex was recorded between 3,929 and 3,797 cal yr BP, showing the greatest abundance but lower diversity of dinocysts. This assemblage might indicate the occurrence of 'opportunistic species' suggesting a high input of freshwater by surface runoff. The low diversity of microplankton associations may be indicative of stressed, restricted conditions with often unstable salinities (Gorin and Steffen, 1991). According to Sluijs (2006), the sediments deposited under low-oxygen conditions show reduced cyst diversities and high abundance of a single species. The low dinoflagellate production suggested by the sparse dinocyst occurrences may be related to low and variable salinities and/or turbulence which inhibits dinoflagellate production (de Vernal and Giroux, 1991). At the same time, the replacement of a varied mollusk assemblage, characterized by venerids and other bivalves including mollusks, gastropods and chitons, by an almost monospecific assemblage (Mytilus Hupé in Gay 1854 and Hiatella Sowerby 1834) tolerant to low or variables salinities suggested a high seasonal freshwater input by river discharge and/or glacial meltwater
(Candel et al., 2009). The interval between 3,797 and 3,164 cal yr BP was characterized by an increase of the species diversity and a decrease of the dinocysts concentration. The assemblage composed by Echinidinium granulatum, Echinidinium delicatum Zonneveld 1997, Echinidinium spp., Islandinium minutum, accompanied by Selenopemphix spp., Brigantedinium simplex, cf. Pentapharsodinium dalei, and Spiniferites spp., suggested environmental conditions comparable with those at the beginning of the sequence (Candel et al., 2009; Candel, 2010). The palynofacies analysis of Río Ovando showed high frequencies of mostly translucent phytoclasts associated with sporomorphs and freshwater algae, suggesting high fluvial input into the marine environment with relatively short distances and/or times of transport, related to the proximity of a terrestrial source. Also, these samples showed low percentages of AOM content suggesting oxic to dysoxic conditions in the depositional environment with good to moderate bottom water ventilation (Roncaglia, 2004; Candel, 2010; Candel et al., 2013).

In the same sector of the channel, the Arroyo Baliza section (site 5, Figs. 1, 4 and 7) (3,499-2,595 cal yr BP) is located closer to the previous locality (site 4), although with a more open geographic setting influenced by the open seawaters of the Beagle Channel. Consequently, the record from this section show that aquatic palynomorphs are represented by 18 dinoflagellate cyst taxa (mainly Brigantedinium simplex, Brigantedinium spp., Polykrikos schwartzii, Echinidinium granulatum, Dubridinium sp., Polykrikos kofoidii, Selenopemphix nephroides, S. quanta and Islandinium cezare (de Vernal et al. 1989 ex de Vernal in Rochon et al. 1999) Head et al., 2001. The acritarchs Halodinium sp., Palaeostomocystis fritilla, P. subtilitheca and P. sp1 (Fig. 6) are also

Figure 6. Photomicrographs of the main aquatic palynomorphs identified in fossil marine sediments from the Beagle Channel. Scale bar is 10 $\mu \mathrm{m}$. Sample number followed by England Finder coordinates. 1, Brigantedinium cariacoense, LGC AB25-B25/2 (in Candel et al., in press); 2, Brigantedinium simplex, LGC AB9-A33/2; 3, Dubridinium sp., LGC AB22-S20/3 (in Candel et al., in press); 4, Quinquecuspis concreta, LGC AB5-P35/4 (in Candel et al., in press); 5, Votadinium calvum, LGC AB21-V25 (in Candel et al., in press); 6, Votadinium spinosum, UNSP AL2638-Q47/4 (in Candel and Borromei, 2013); 7, Selenopemphix nephroides, UNSP BL1631a-C22/2 (in Candel and Borromei, 2013), 8, Selenopemphix quanta, UNSP R01972b-M38/2 (in Candel et al., 2009); 9, Islandinium minutum, UNSP R01968-S14/2 (in Candel and Borromei, 2013); 10, Is/andinium cezare, LGC AB18-U20/1 (in Candel et al., in press); 11, Echinidinium granulatum, LGC AB11-W41 (in Candel et al., in press); 12, Operculodinium centrocarpum, UNSP RV1532a-F23/3 (in Candel and Borromei, 2013); 13, Spiniferites ramosus, LGC AB1-Q24/4 (in Candel et al., in press); 14, Spiniferites sp., UNSP BL843a-K53 (in Candel and Borromei, 2013); 15, Polykrikos kofoidii, LGC AB4-M34/4 (in Candel et al., in press); 16, Polykrikos schwartzii, LGC AB4-013 (in Candel et al., in press); 17, Halodinium sp., UNSP R01972c-R13 (in Candel et al., 2009); 18, Zygnema sp., LGC AS19-H15/3; 19, Palaeostomocystis fritilla, LGC AB12-J25/2; 20, Palaeostomocystis subtilitheca, LGC AB10-H11/1 (in Candel et al., in press). 

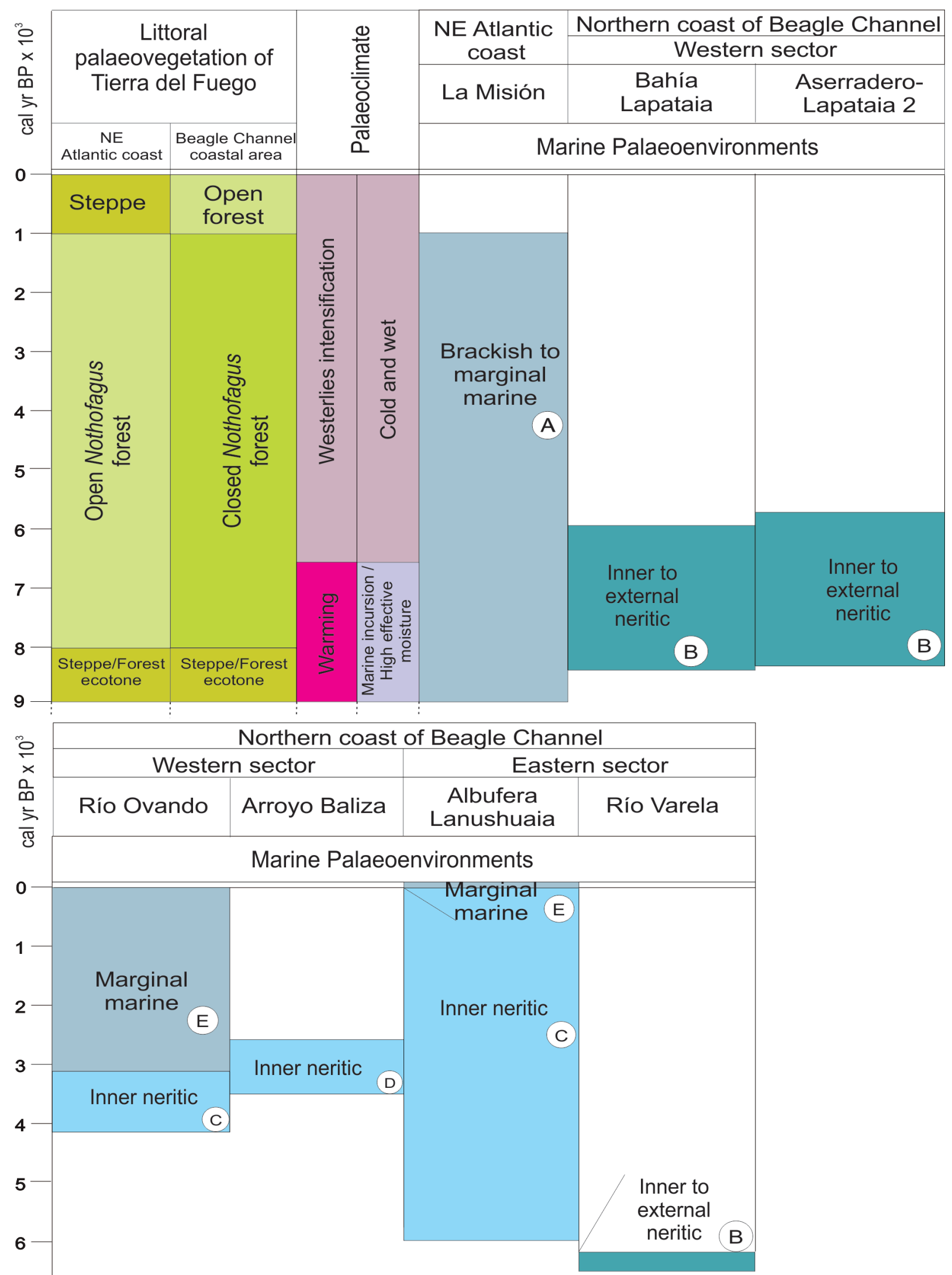
present together with foraminiferal linings, copepod eggs and freshwater to brackish-marine algae (Zygnema sp., Spirogyra sp., Cymatiosphaera sp., Tasmanites sp.). The palynological records from the Arroyo Baliza site have a similar composition to those observed in surface samples from the Beagle Channel (Candel et al., 2012), with a higher diversity of dinoflagellate cyst species, suggesting that the environmental conditions during the late Holocene are comparable to today. It indicates that most of the marine species were able to persist in the area even during neoglacial climatic deterioration (Candel et al., in press). A preliminary palynofacies analysis of Arroyo Baliza showed a dominance of translucent phytoclasts, mainly non-structured, degraded and pale in colour, with some of them in transition to amorphous organic matter (Rabassa et al., 2009). The high numbers of translucent phytoclasts indicate the proximity of a continental source to the marine depositional environment and thus a relatively short transportation time.

\section{Late Holocene marine palynomorph assemblages}

Palaeoclimatic records from southern South America during the last 1,000 cal yr BP, indicate a general trend of decreasing temperature (reduced insolation) and an increase in the westerly winds intensity, culminating with the Little Ice Age event (ca.600-100 yr BP) (Moy et al., 2009). Marine records from the Chilean continental shelf $\left(41^{\circ} \mathrm{S}\right)$ show cooling surface seawater temperature about $\sim 1.5^{\circ} \mathrm{C}$ (Lamy et al., 2001) and $1^{\circ} \mathrm{C}$ (Mohtadi et al., 2007) from 2,000 cal yr BP culminating in the last 100 years, probably due to the northward shift in the Antarctic Circumpolar Current and the westerly winds (Moy et al., 2009).

The uppermost section in Río Ovando (site 4, Figs. 5 and 7) recorded a decrease in the Nothofagus and an increase in grass and shrub associated with an increase of Prasinophyceae (Cymatiosphaera (Wetzel) Deflandre 1954) and Zygnemataceae (Spirogyra Link 1820) algae. This palynomorph assemblage suggested the development of an open Nothofagus forest with areas of grassland and shrubs, with river discharge to the marine environment indicated by the occurrence of freshwater to brackish aquatic palynomorphs related to a sea-level regressive event (Candel, 2010).

On the other hand, eastwards in Beagle Channel, at Albufera Lanushuaia (site 6, Figs. 5 and 7) showed similar conditions after 1958 cal yr AD to those observed in the uppermost section of Río Ovando. The development of an open forest of Nothofagus is accompanied with an increase in herb-shrub vegetation and by an increase in copepod eggs and foraminiferal linings reflecting the proximity of marine environments (Candel et al., 2011).

\section{FINAL REMARKS}

The Early Holocene climatic amelioration, following by a deglaciation, was accompanied by a marine transgression in Tierra del Fuego. During the marine incursion the vegetation in the coastal areas along the Beagle Channel was mainly arboreal with a dominance of a Nothofagus forest and scarcity of shrub and herbaceous communities indicative of high effective moisture conditions caused by the moderating action of the sea. Also, in the northeastern Atlantic coast the treeless steppe was replaced by a relatively open Nothofagus forest at times of the Holocene marine transgression. The cold and wet conditions during the Middle to Late Holocene favored the regional expansion of a closed-canopy Nothofagus forest. During the last 1,000 years $\mathrm{BP}$, the littoral vegetation along the Beagle Channel

Figure 7. Palaeoenvironmental correlation of the Holocene marine deposits from Tierra del Fuego. A, Diatoms: Melosira sulcata, Actinoptychus undulatus, Hyalodiscus. Ostracodes: Loxoreticulatum fallax, Loxocythere sp., Cytherura, Cytheromorpha, Perissocytheridea. B, Organic-walled dinocyst assemblage: Brigantedinium spp., Selenopemphix nephroides, S. quanta, Polykrikos schwartzii, Spiniferites sp., Operculodinium centrocrapum. C, Organic-walled dinocyst assemblage: Brigantedinium spp., Islandinium minutum, Echinidinium spp., Selenopemphix nephroides, S. quanta, Votadinium spinosum, Polykrikos kofoidii, P. schwartzii, cf. Pentapharsodinium dalei, cf. Dubridinium sp. D, Organic-walled dinocyst assemblage: Brigantedinium cariacoense, B. simplex, Dubridinium caperatum, Echinidinium delicatum, E. granulatum, Islandinium cezare, I. minutum, cyst of Pentapharsodinium dalei, Polykrikos schwartzii, P. kofoidii, Quinquecuspis concreta, Selenopemphix nephroides, S. quanta, Trinovantedinium applanatum, Votadinium calvum, V. spinosum, Operculodinium centrocarpum, Spiniferites ramosus. E, Aquatic palynomorphs assemblage: foraminiferal linings, copepod eggs, Prasinophyceae and Zygnemataceae. 
coast was characterised by an open Nothofagus forest and the development of peatlands, while in the northeastern Atlantic coast the steppe vegetation developed under less humid environmental conditions related to a regressive event.

The Holocene marine sediments were characterized by marine palynomorph assemblages dominated by Peridiniales taxa that suggested the development of low energy estuarine environments with low-salinities due to glacier meltwater discharge. These environments would have persisted as the influence of seawater was expanding by global eustatic rise. The increasing salinity was accompanied by an increase in biodiversity in both dinoflagellate cysts and mollusks assemblages.

The marine assemblages recorded in the Middle and Late Holocene sediments (Albufera Lanushuaia, Río Ovando, and Arroyo Baliza sites) showed greater species diversity of dinocysts than those identified in the marine deposits of Early to Mid-Holocene age (Bahía Lapataia and Río Varela sites). This species diversification suggests an increase in marine palaeoproductivity caused by the input of terrigenous nutrients by water runoff probably related to a precipitation increase. Palaeoclimatic evidence from Tierra del Fuego show an increase in precipitation after ca. 6,000 yr BP caused by an intensification and/or latitudinal migration of the Westerlies (Markgraf and Huber, 2010).

The Late Holocene marine assemblages have a similar composition to those observed in the surface samples from the Beagle Channel. A higher diversity of dinocyst species was observed in comparison to the Early Holocene assemblages, suggesting palaeoenvironmental conditions comparable to today in the Beagle Channel. Probably, most of the marine species were able to persist in the area even during minor climatic fluctuations.

The palynofacies analysis indicates continental supply to marine environments coming from nearby sectors, and without significant transport. The dominance of translucent phytoclasts associated with pyrite suggests reducing conditions, probably related to marginal-marine environments. Also, high frequencies of $A O M$ indicate the proximity of a terrestrial source with high organic matter input into the aquatic environment combined with favorable conditions for bacterial action.

\section{ACKNOWLEDGEMENTS}

This work is dedicated to Prof. Dr. Mirta Elena Quattrocchio, who the authors considered as their "scientific mother". We would like to give a special tribute to Mirta for being a figurehead woman in the field of Argentinian Palynology, a model for generations of young Palynologists in Argentina (and elsewhere), especially in marine and terrestrial studies of Mesozoic and Cenozoic. The authors are also grateful to Marcelo A. Martínez and Lorena L. Musotto (INGEOSUR-CONICET, Universidad Nacional del Sur, Argentina), Juan Federico Ponce and Andrea Coronato (CADIC-CONICET, Ushuaia, Argentina) for field assistance and contributing resources in the field work. We thank Marcelo A. Martínez and Daniela E. Olivera for invited us to contribute to this volume and for their editorial support, and also to two reviewers for their constructive comments that helped to improve our manuscript. This paper was funded by grants PIP 11220100100041 (CONICET) and PGI 24/H126 (Secretaría General de Ciencia y Tecnología, UNS).

\section{REFERENCES}

Bentley, M.J., Hodgson, D.A., Smith, J.A., Cofaigh, C.O., Domack, E.W., Larter, R.D., Roberts, S.J., Brachfeld, S., Leventer, A., Hjort, C., Hillenbrand, C.-D., and Evans, J. 2009. Mechanisms of Holocene palaeoenvironmental change in the Antarctic Peninsula region. The Holocene 19: 51-69.

Borromei, A.M. 1995. Análisis polínico de una turbera holocénica en el Valle de Andorra, Tierra del Fuego, Argentina. Revista Chilena de Historia Natural 68: 311-319.

Borromei, A.M., Coronato, A., Franzén, L.G., Ponce, J.F., López Sáez, J.A., Maidana, N., Rabassa, J., and Candel, M.A. 2010. Multiproxy record of Holocene paleoenvironmental change, Tierra del Fuego, Argentina. Palaeogeography, Palaeoclimatology, Palaeoecology 286: 1-16.

Borromei, A.M., Coronato, A., Quattrocchio, M., Rabassa, J., Grill, S., and Roig, C. 2007. Late Pleistocene-Holocene environments in Valle Carbajal, Fuegian Andes valley, southern South America. Journal of South American Earth Sciences 23: 321-335.

Borromei, A.M., Ponce, J.F., Coronato, A., Candel, M.S., Olivera, D., and Okuda, M. 2014. Reconstrucción de la vegetación posglacial y su relación con el ascenso relativo del nivel del mar en el extremo este del canal Beagle, Tierra del Fuego. Andean Geology 41: 362-379.

Borromei, A.M., and Quattrocchio, M. 2001. Palynological study of Holocene marine sediments from Bahía Lapataia, Beagle Channel, Tierra del Fuego, Argentina. Revista Española de Micropaleontología 33: 61-70.

Borromei, A.M., and Quattrocchio, M. 2007. Palynology of Holocene marine deposits at Beagle Channel, southern Tierra del Fuego, Argentina. Ameghiniana 41: 161-171.

Borromei, A.M., and Quattrocchio, M. 2008. Late and Postglacial Paleoenvironments of Tierra del Fuego: terrestrial and marine palynological evidence. In: J. Rabassa (Ed.), The Late Cenozoic of Patagonia and Tierra del Fuego. Developments in Quaternary Science, 11, Elsevier, p. 369-381.

Bujalesky, G., Coronato, A., Roig, C., and Rabassa, J. 2004. Holocene differential tectonic movements along the argentine sector of the Beagle Channel (Tierra del Fuego) inferred from marine palaeoenvironments. Bollettino di Geofisica Teorica e Applicata 45: 235-238.

Candel, M.S. 2010. [Cambios relativos del nivel del mar en el Canal Beagle, Tierra del Fuego (Cenozoico Tardío), en base al análisis palinológico. Ph.D. Thesis, Universidad Nacional del Sur, Departa- 
mento de Geología, Bahía Blanca, 194 p. Unpublished.].

Candel, M.S., and Borromei, A.M. 2013. Caracterización taxonómica y paleoecológica de la ingresión del Holoceno en el Canal Beagle (Tierra del Fuego), en base a las asociaciones de dinoquistes y otros palinomorfos acuáticos. Revista Brasileira de Paleontología 16: 245-262.

Candel, M.S., Borromei, A.M., Martínez, M.A., and Bujalesky, G. 2013. Palynofacies analysis of surface sediments from Beagle Channel and its application as modern analogues for Holocene records of Tierra del Fuego, Argentina. Palynology 37: 62-76.

Candel, M.S., Borromei, A.M., Martínez, M.A., Gordillo, S., Quattrocchio, M., and Rabassa, J. 2009. Middle-Late Holocene palynology and marine mollusks from Archipielago Cormoranes area, Beagle Channel, southern Tierra del Fuego, Argentina. Palaeogeography, Palaeoclimatology, Palaeoecology 273: 111-122.

Candel, M.S., and Louwye, S. 2015. Palaeoenvironmental conditions during the Holocene transgressive-regressive event in the Beagle Channel, Tierra del Fuego, southern Argentina. $6^{\circ}$ Congreso Argentino de Cuaternario y Geomorfología (Ushuaia), Actas: 140.

Candel, M.S., Louwye, S., and Borromei, A.M. In press. Reconstruction of the late Holocene paleoenvironment of the western Beagle Channel (Argentina) based on a palynological analysis. Quaternary Internationaldoi: http://dx.doi.org/10.1016/j.quaint.2016.01.074.

Candel, M.S., Martínez, M.A., and Borromei, A.M. 2011. Palinología y palinofacies de una secuencia marina del Holoceno mediotardío: Albufera Lanushuaia, Canal Beagle, Tierra del Fuego, Argentina. Revista Brasileira de Paleontología 14: 297-310.

Candel, M.S., Radi, T., de Vernal, A., and Bujalesky, G. 2012. Distribution of dinoflagellate cysts and other aquatic palynomorphs in surface sediments from the Beagle Channel, southern Argentina. Marine Micropaleontology 96-97: 1-12.

Codignotto, J.O., Kokot, R.R., and Marcomini, S.C. 1992. Neotectonism and sea level changes in the coastal zone of Argentina. Journal of Coastal Research 8: 125-133.

de Vernal, A., and Giroux, L. 1991. Distribution of organic walled microfossils in recent sediments from the Estuary and Gulf of St. Lawrence: some aspects of the organic matter fluxes. Canadian Journal of Fisheries and Aquatic Sciences 113: 189-199.

de Vernal, A., Henry, M., Matthiessen, J., Mudie, P., Rochon, A., Boessenkool, K., Eynaud, F., Grøsfjeld, K., Guiot, J., Hamel, F., Harland, R., Head, M., Kunz-Pirrung, M., Levac, E., Loucheur, V., Peyron, O., Pospelova, V., Radi, T., Turon, J.-L., and Voronina, E. 2001. Dinoflagellate cyst assemblages as tracers of sea-surface conditions in the northern North Atlantic, Arctic and subArctic seas: the new ' $n=677$ ' data base and its application for quantitative palaeoceanographic reconstruction. Journal of Quaternary Science 16: 681-698.

de Vernal, A., Hillaire-Marcel, C., Rochon, A., Fréchette, B., Henry, M., Solignac, S., and Bonnet, S. 2013. Dinocyst-based reconstructions of sea ice cover concentration during the Holocene in the Arctic Ocean, the northern North Atlantic Ocean and its adjacent seas. Quaternary Science Reviews 79: 111-121.

Fernández, M., Candel, S., Ponce, J.P., and Rabassa, J. 2014. Primeras evidencias de la transgresión marina del Holoceno medio en la Isla de los Estados (Tierra del Fuego) a partir de estudios de palinomorfos acuáticos y diatomeas. $19^{\circ}$ Congreso Geológico Argentino (Córdoba), Actas: 17-10.

Fleming, K., Johnston, P., Zwartz, D., Yokoyama, Y., Lambeck, K., and Chappell, J. 1998. Refining the eustatic sea level curve since the Last Glacial Maximum using far- and intermediate field sites. Earth and Planetary Science Letters 163: 327-342.

Gordillo, S. 1993. Las terrazas marinas holocenas de la región del
Beagle (Tierra del Fuego) y su fauna asociada. $12^{\circ}$ Congreso Geológico Argentino (Mendoza), Actas 6: 34-39.

Gordillo, S. 1999. Holocene molluscan assemblages in the MageIlan Region. Scientia Marina 63: 15-22.

Gordillo, S., Brey, T., Beyer, K., and Lomovasky, B.J. 2015. Climatic and environmental changes during the middle to late Holocene in southern South America: A sclerochronological approach using the bivalve Retrotapes exalbidus (Dillwyn) from the Beagle Channel. Quaternary International 377: 83-90.

Gordillo, S., Coronato, A., and Rabassa, J. 1993. Late Quaternary evolution of a subantarctic paleofjord, Tierra del Fuego. Quaternary Science Reviews 12: 889-897.

Gordillo, S., Coronato, A., and Rabassa, J. 2005. Quaternary molluscan faunas from the island of Tierra del Fuego after the Last Glacial Maximum. Scientia Marina 69: 337-348.

Gorin, G.E., and Steffen, D. 1991. Organic facies as a tool for recording eustatic variations in marine fine-grained carbonates-example of the Berriasian stratotype at Berrias (Ardèche, SE France). Palaeogeography, Palaeoclimatology, Palaeoecology 85: 303-320.

Grill, S., Borromei, A.M., Quattrocchio, M., Coronato, A., Bujalesky, G., and Rabassa, J. 2002. Palynological and sedimentological analysis of Recent sediments from Río Varela, Beagle Channel, Tierra del Fuego, Argentina. Revista Española de Micropaleontología 34: 145-161.

Heusser, C.J. 1989. Late Quaternary Vegetation and Climate of Southern Tierra del Fuego. Quaternary Research 31: 396-406.

Heusser, C.J. 1998. Deglacial paleoclimate of the American sector of the Southern Ocean: Late Glacial-Holocene records from the latitude of Beagle Channel ( $\left.55^{\circ} \mathrm{S}\right)$, Argentine Tierra del Fuego. Palaeogeography, Palaeoclimatology, Palaeoecology 141: 277-301.

Heusser, C.J. 2003. Ice age southern Andes - A chronicle of paleoecological events. Developments in Quaternary Science, 3. Elsevier, Amsterdam, $240 \mathrm{p}$.

Heusser, C.J., and Rabassa, J. 1987. Cold climatic episode of Younger Dryas Age in Tierra del Fuego. Nature 328: 609-611.

Heusser, C.J. ,and Rabassa, J. 1995. Late Holocene forest-steppe interaction at Cabo San Pablo, Isla Grande de Tierra del Fuego, Argentina. Quaternary of South America and Antarctic Peninsula 9: 179-188.

Isla, F., and Bujalesky, G. 2008. Coastal Geology and Morphology of Patagonia and the Fuegian Archipelago. In: J. Rabassa (Ed.), The Late Cenozoic of Patagonia and Tierra del Fuego. Developments in Quaternary Science, 11, Elsevier, p. 227-239.

Lamy, F. Hebbeln, D., Röhl, U., and Wefer, G. 2001. Holocene rainfall variability in southern Chile: a marine record of latitudinal shifts of the Southern Westerlies. Earth and Planetary Science Letters 185: 369-382.

Markgraf, V. 1980. New data on the late- and postglacial vegetational history of La Misión, Tierra del Fuego, Argentina. Proceedings $4^{\text {th }}$ International Palynological Conference (Lucknow, India), 3: 68-74.

Markgraf, V. 1983. Late and postglacial vegetational and paleoclimatic changes in subantarctic, temperate and arid environments in Argentina. Palynology 7: 43-70.

Markgraf, V. 1993. Paleoenvironments and paleoclimates in Tierra del Fuego and southernmost Patagonia, South America. Palaeogeography, Palaeoclimatology, Palaeoecology 102: 53-68.

Markgraf, V., and Huber, U.M. 2010. Late and postglacial vegetation and fire history in Southern Patagonia and Tierra del Fuego. Palaeogeography, Palaeoclimatology, Palaeoecology 297: 351366. 
Mauquoy, D., Blaauw, M., van Geel, B., Borromei, A.M., Quattrocchio, M.E., Chambers, F., and Possnert, G. 2004. Late-Holocene climatic changes in Tierra del Fuego based on multi-proxy analyses of peat deposits. Quaternary Research 61: 148-158.

Mohtadi, M., Romero, O.E., Kaiser, J., and Hebbeln, D. 2007. Cooling of the southern high latitudes during the Medieval Period and its effect on ENSO. Quaternary Science Reviews 26: 1055-1066.

Moy, C.M., Moreno, P.I., Dunbar, R.B., Francois, J.P., Kaplan, M.R., Villalba, R., and Haberzettl, T. 2009. Climate change in southern South America during the last two millennia. In: F. Vimeux, F. Sylvestre, and M. Khodri (Eds.), Past Climate Variability in South America and Surrounding Regions: From the Last Glacial Maximum to the Holocene. Springer Science and Business Media, (Developments in Paleoenvironmental Research Series), p. 353-393.

Musotto, L.L. 2013. [Paleoambientes y paleoclimas del Cuaternario tardío en turberas del centro de la Isla Grande de Tierra del Fuego en base al análisis palinológico. Ph.D. Thesis, Universidad Nacional del Sur, Departamento de Biología, Bioquímica y Farmacia, Bahía Blanca, 243 p. Unpublished.].

Musotto, L.L., Borromei, A.M., Coronato, A., Menounos, B., Osborn, G., and Marr, R. 2016a. Late Pleistocene and Holocene palaeoenvironmental changes in central Tierra del Fuego $\left(\sim 54^{\circ} \mathrm{S}\right)$ inferred from pollen analysis. Vegetation History and Archaeobotany 25: 117-130.

Musotto, L.L., Borromei, A.M., Bianchinotti, M.V., and Coronato, A. in press. Late Quaternary palaeoenvironmental reconstruction of central Tierra del Fuego (Argentina) based on main fossil pollen and fungi. Quaternary International. http://dx.doi.org/10.1016/ j.quaint.2016.01.071.

Pisano, E. 1977. Fitogeografía de Fuego-Patagonia Chilena. I.- Comunidades vegetales entre las latitudes $52^{\circ}$ y $56^{\circ} \mathrm{S}$. Anales Instituto de la Patagonia 8: 121-250.

Prohaska, F. 1976. The climate of Argentina, Paraguay and Uruguay. In: W. Schwerdfeger (Ed.), Climates of Central and South America. World Survey of Climatology, 12, Elsevier, p. 3-112.

Quattrocchio, M., and Borromei, A.M. 1998. Paleovegetational and paleoclimatic changes during the late Quaternary in southwestern Buenos Aires Province and southern Tierra del Fuego (Argentina). Palynology 22: 67-82.

Rabassa, J. 2008. Late Cenozoic glaciations in Patagonia and Tierra del Fuego. In: J. Rabassa (Ed.), The Late Cenozoic of Patagonia and Tierra del Fuego. Developments in Quaternary Science, 11, Elsevier, p. 151-204.

Rabassa, J., Coronato, A., Bujalesky, G., Salemme, M., Roig, C., Meglioli, A., Heusser, C., Gordillo, S., Roig, F., Borromei, A., and Quattrocchio, M. 2000. Quaternary of Tierra del Fuego, Southernmost South America: an updated review. Quaternary International 68-71: 217-240.

Rabassa, J., Coronato, A., Gordillo, S., Candel, M.S., and Martínez, M.A. 2009. Paleoambientes litorales durante el inicio de la transgresión marina holocena en Bahía Lapataia, Canal Beagle, Parque Nacional Tierra del Fuego. Revista de la Asociación Geológica Argentina 65: 648-659.
Rabassa, J., Coronato, A., and Martínez, O. 2011. Late Cenozoic glaciations in Patagonia and Tierra del Fuego: an updated review. Biological Journal of the Linnean Society 103: 316-335.

Rabassa, J., Heusser, C.J., and Stuckenrath, R. 1986. New data on Holocene sea transgression in the Beagle Channel: Tierra del Fuego, Argentina. Quaternary of South America and Antarctic Peninsula 4: 291-309.

Radi, T., and de Vernal, A. 2008. Cysts as proxy of primary productivity in mid-high latitudes of the Northern Hemisphere. Marine Micropaleontology 68: 84-114.

Reimer, P., Bard, E., Bayliss, A., Warren Beck, J., Blackwell, P., Bronk Ramsey, C., Buck, C., Cheng, H., Edwards, L., Friedrich, M., Grootes, P., Guilderson, T., Haflidason, H., Hajdas, I., Hatté, C., Heaton, T., Hoffmann, D., Hogg, A. Hughen, K., Kaiser, F., Kromer, B., Manning, S., Niu, M., Reimer, R., Richards, R., Scott, M., Southon, J., Staff, R., Turney, C., and van der Plicht, J. 2013. Intcal 13 and Marine13 radiocarbon age calibration curves 050,000 yr cal BP. Radiocarbon 55: 1869-1887.

Roncaglia, L. 2004. Palynofacies analysis and organic-walled dinoflagellate cysts as indicators of palaeo-hydrographic changes: an example from Holocene sediments in Skálafjord, Faroe Islands. Marine Micropaleontology 50: 21-42.

Sluijs, A. 2006. Global change during the Paleocene-Eocene thermal maximum. LLP Foundation. $227 \mathrm{p}$.

Stuiver, M., Reimer, P.J., and Reimer, R.W. 2015. Calib 7.1. http://calib.qub.ac.uk/calib/.

Tuhkanen, S. 1992. The climate of Tierra del Fuego from a vegetation geographical point of view and its ecoclimatic counterparts elsewhere. Acta Botanica Fennica 125: 4-17.

Waldmann, N., Borromei, A.M., Recasens, C., Olivera, D., Martínez, M.A., Maidana, N.I., Ariztegui, D., Austin, J.A. Jr, Anselmetti, F.S., and Moy, C.M. 2014. Integrated reconstruction of Holocene millennial-scale environmental changes in Tierra del Fuego, southernmost South America. Palaeogeography, Palaeoclimatology, Palaeoecology 399: 294-309.

Doi: 10.5710/PEAPA.16.08.2016.112

Recibido: 28 de marzo de 2016

Aceptado: 16 de agosto de 2016 